\title{
Direitos humanos: é pra ler ou pra viver?
}

\author{
Thallyta Laryssa P. Ferreira \\ (Aluna do curso de Direito da PUC RIO)
}

O conceito de direitos humanos é abrangente e está em constante mutação. Todavia, o que não pode ocorrer é se utilizar da existência de uma divergência de percepções acerca desta e de outras temáticas como justificativa para a não realização de atos em prol da humanidade, pois para lutar por direitos humanos basta compreender que todos somos sujeitos de direitos e merecedores de respeito.

Há diversas convenções, declarações, entre outros documentos que versam acerca da temática dos direitos humanos. A declaração universal dos direitos humanos de 1948, de forma muito objetiva, fundamentou a necessidade de se defender os direitos humanos para todos indistintamente, por sermos todos humanos, além de estabelecer que estes deveriam ser garantidos universalmente e de forma indivisível.

Infelizmente, muitos direitos foram assegurados somente no papel, apenas nas declarações, convenções, entre outros documentos, e ainda, só para algumas pessoas. Defende-se universalmente o direito à liberdade de expressão e ainda assim, pessoas são presas por dizerem o que pensam; o direito à alimentação existe e milhares de crianças morrem de fome todos os dias; o direito a ter uma vida digna está em Constituições pelo mundo e ainda há pessoas sendo escravizadas. 
Havia uma época em que a escravidão era permitida e que a riqueza de um homem era medida pela quantidade de escravos que ele possuía, já em outra época o valor de um homem era dado de acordo com a quantidade de terras que ele possuía. Por muito tempo o valor dos homens tem sido atribuído com base no valor de seus bens materiais, será que algum dia essa concepção será superada? Será que um dia o homem será verdadeiramente valorizado simplesmente por ser humano?

Ademais, podemos fazer menção à outra constatação de situação igualmente injusta, porém de inegável violação aos direitos humanos, que é a de que os seres humanos são recorrentemente divididos e rotulados. Seja com base no sexo, seja com base na cor de sua pele, os indivíduos são previamente catalogados e a partir da categoria na qual se enquadram, os direitos vão sendo distribuídos de forma subjetiva e arbitrária.

Exemplificando tal afirmação podemos mencionar 0 fato de que em um passado não tão distante anúncios de emprego faziam menção à "boa aparência" como pré-requisito para se candidatar a determinada oportunidade laboral e que mais tarde restou comprovado que ter boa aparência significava que negros não eram aceitos, pois boa aparência era a aparência branca. Então, cor é mais importante que capacidade?

Há poucos meses o mundo ficou pasmo com um vídeo que mostrava a venda de escravos negros na Líbia, muitos se pronunciaram, a mídia falou muito sobre o tema, todavia não vimos qualquer atitude para resolver o problema de fato. Então, vender jornais, ou mesmo ter audiência é o que importa? Salvar 
vidas é preocupação secundária?

Há quase dois meses foram relatados casos de racismo nos jogos jurídicos estaduais de 2018. Muitos defenderam que os reais culpados fossem punidos. Movimentos estudantis se manifestaram e expuseram um problema que claramente assola nossa sociedade e universidade: o racismo. Contudo, nenhuma mudança estrutural foi feita em nosso ambiente acadêmico. Então, discursos são suficientes para resolver um problema que data do período colonial?

Em pleno século XXI ainda vemos episódios lastimáveis que não apenas atentam contra normas legais, mas violam direitos humanos, direitos estes que nossa Carta Magna e demais documentos pelo mundo afirmam serem devidos a todos, por todos. Continuaremos inertes? Como pensar em um futuro diferente?

É fundamental que a percepção de que os direitos humanos não devem ser apenas palavras em um papel, mas conquistados e assegurados no dia a dia seja reafirmada e que se entenda que respeitar o outro, independentemente de ele pensar como nós ou gostar do que gostamos é vital.

Além disso, é crucial que se adote uma posição ativa de luta pelos direitos de todos e por isso, se faça escolhas que sejam as melhores possíveis para todos os seres humanos para que se possa assegurar uma vida digna e de qualidade para todos.

Respeitar e defender os direitos humanos são deveres de todos, pois independentemente de percepções, entender que o outro merece respeito e cuidado, não é apelo a palavras 
escritas em papéis ou ao dito por grandes pensadores, mas um clamor para que se volte à essência do ser, à própria consciência humana.

$\mathrm{Na}$ história encontramos exemplos de pessoas que lutaram em defesa dos seres humanos e seus direitos por entender o valor inestimável que o ser humano tem em si mesmo. Dentre estas podemos citar: o Pastor Martin Luther King Jr e sua luta pelo fim da segregação racial nos EUA; o expresidente Nelson Mandela e sua luta pelo fim da segregação racial na África do Sul e ainda, Mahatma Gandhi e sua luta pacífica pela independência da Índia.

Grandes feitos tais figuras realizaram, e com meios quantitativa e qualitativamente inferiores aos nossos. Indago-me então: O que será que nós somos capazes de promover se nos unirmos para fazer a diferença? Qual o limite? Se é que existe algum.

Visando uma efetiva mudança no mundo e que os direitos de todos sejam verdadeiramente respeitados, é fundamental que o desejo de mudança se origine em nós. Tem que partir de nós o desejo de revolução de mentes e estruturas, pois somos nós o motor para que a mudança se concretize.

Precisamos começar hoje, não amanhã, mas hoje, a rever condutas, ir para além de discursos e agir em prol da efetivação dos direitos de todos, pois como dizia Mahatma Gandhi: "Seja a mudança que você quer no mundo". 